\title{
Enhanced haemagglutination and phytochemical evaluation suggest significant presence of glycoproteins (Lectins) in semi-purified fractions of eastern Nigeria Mistletoe, Loranthus micranthus Linn.
}

\author{
Edwin Ogechukwu Omeje ${ }^{1,3,4 *}$, Patience Ogoamaka Osadebe ${ }^{1}$, Ugwuoke Christopher $^{2}$ and Pamela Chinenye Akaraekwe \\ ${ }^{1}$ Department of Pharmaceutical and Medicinal Chemistry, University of Nigeria, 41001, Nsukka, Nigeria \\ ${ }^{2}$ Department of Pharmacognosy and Enviromental Medicine, Faculty of Pharmaceutical Sciences, University of Nigeria, 41001, Nsukka \\ ${ }^{3}$ Division of Endocrinology, CSIR-Central Drug Research Institute, Chattar Manzil, P.O. Box 173, 226001, Lucknow, India \\ ${ }^{4}$ Division of Medicinal \& Process Chemistry, CSIR-Central Drug Research Institute, Chattar Manzil, P.O. Box 173, 226001, Lucknow, India
}

\begin{abstract}
In an attempt to obtain evidence for the presence or otherwise of lectins in extracts of the eastern Nigeria mistletoes, we carried out partial purification of glycoproteinrich fraction using ammonium sulphate based method in a dialysing membrane. Briefly, $1 \mathrm{~kg}$ each of mistletoe leaves parasitic on Kola acuminata, Pentaclathra macrophylla and Persia americana were extracted using chilled maceration in sterile distilled water. Purification steps comprising centrifugation, fractionation, filtration and dialysis were used to purify the protein (lectin) extracted from the leaves of Loranthus micranthus (mistletoe) parasitic on Kola acuminata, Pentaclathra macrophylla and Persia americana. Result obtained showed extract yields of $22 \%, 18 \%$ and $25 \%$ respectively and that the purified protein-rich fractions agglutinated nonspecific mouse erythrocyte at different intensity. Specifically, dialyzed fraction from Kola acuminata showed very strong agglutination compared to other fractions and Phosphate buffered saline (PBS). Phytochemical evaluation showed presence of only carbohydrate and proteins in obtained fractions compared to numerous phytoconstituents in the crude extracts. The present study strongly suggests the presence of lectin-like proteins in the partially purified extracts of the eastern Nigeria mistletoes mostly in that from Kola acuminata. Also, further purification of lectins using affinity chromatography will give a high haemagglutination activity.
\end{abstract}

\section{Introduction}

Glycoproteins (lectins) from European and Korean mistletoes have been demonstrated to exhibit potent immunomodulatory, mucosal (cellular and humoral) adjuvanting, mitogenic nitric oxide induction, apoptotic, antitumor and Toll-Like Receptor-4 (TLR4)-mediated activation of mouse macrophages activities. The outstanding cytotoxic and immunomodulatory effects of mistletoe lectin have made it a subject of great interest to scientists from countries with medicinally important mistletoe populations [1]. Four years ago, Korean mistletoe lectin was shown to potently enhance dendritic cell maturation via the TLR4 signalling pathway [2]. Although still under intensive scientific scrutiny for possible validation and approval, the European mistletoes have long ago become part of clinical armamentarium against certain tumours. Generally, lectins are carbohydrate-binding proteins with various biological activities, such as anti-tumour and immunomodulatory effects $[3,4]$. Recently, lectins have been examined as potential therapeutic candidates in biological and therapeutic research studies, because of their interactions with receptor-linked glycans on cell surfaces that prime several cell signalling and biological responses [5]. In particular, lectins induce the activations of various immune cells by mainly binding Toll-like receptors (TLRs). Mistletoes are semi-parasitic plants, and extracts of the plant from Europe and Korea have been used to treat various types of cancers [6]. The Mistletoe lectin (ML) is composed of A and B chains linked by a disulfide bond. $\mathrm{ML}$ is a type II ribosome-inactivating protein (RIP) and is composed of a catalytically active A-chain with rRNA N-glycosidase activity, and a B chain with carbohydrate-binding properties [6]. European mistletoe (Viscum album) lectin (EML) is classified according to its carbohydrate specificities as lectin I (D-galactose), lectin II (N-acetylgalactosamine), or lectin III (D-galactose, $\mathrm{N}$-acetyl-galactosamine). EML exhibits immunomodulatory effects, such as, the enhancement of the phagocytic activities and the release of cytokines by of granulocytes and monocytes. Korean mistletoe (Viscum album Coloratum) extract is also reported to have a variety of biological activities (Yoon et al., 2001). Also, Kang et al., 2010 [7] reported that KML induces nitric oxide production and TNF- $\alpha$ secretion in macrophages by TLR4 signalling. Over the years, we have studied the eastern Nigeria mistletoe Loranthus micranthus Linn) and isolated immunomodulatory and antioxidant compounds (novel and known) [8] that showed very potent mitogenic activity on mice splenocytes and increased expression of the CD69 molecule [9]. Recently, studies on this our mistletoes revealed potent osteogenic compounds and it is known that osteogenesis has very

Correspondence to: Edwin Ogechukwu Omeje, Department of Pharmaceutical and Medicinal Chemistry, University of Nigeria, 41001, Nsukka, Nigeria, Tel: +234-803-549-5441; Fax: +234-42-77022; E-mail: edwin.omeje@unn.edu.ng

Key words: glycoproteins, haemagglutination, mistletoes, Nigeria, lectins

Received: January 04, 2015; Accepted: March 27, 2015; Published: April 03, 2015 
Omeje EO (2015) Enhanced haemagglutination and phytochemical evaluation suggest significant presence of glycoproteins (Lectins) in semi-purified fractions of eastern Nigeria Mistletoe, Loranthus micranthus Linn

strong molecular tie with immunology as much as inflammatory pathways, endocrine system and even several other intricate signalling pathways [10]. This observation (the stimulatory effect of CD69 molecule), sharply contrasted an observed cytotoxic action of direct injection of crude Nigerian mistletoe extract into non-melanoma nodular tumor in mice (unpublished data) in addition to the presence of proteins and carbohydrates in the crude extracts and fractions. This seeming contradiction evokes a very strong research query that must be resolved. Taking together, the Nigerian mistletoe contains notable cytotoxic contents which possibly are glyco-proteins (lectins) as have been reported for similar species from other parts of the world. With all these well established data on bioactive lectins of both European and Korean mistletoes, and the established biological activities of the eastern Nigeria mistletoes, it becomes imperative to study the Nigerian mistletoes in the context of the potential biological functions of its probable lectins. This is the thrust of the present research work.

\section{Materials and methods}

\section{Collection and preparation of plant material}

Fresh leaves of Loranthus micranthus parasitic on Kola acuminata, Pentaclathra macrophylla and Persia americana were collected at early hours during September 2014 at Orba in Nsukka local government of Enugu state Nigeria. The plant was authenticated by a taxonomist, $\mathrm{Mr}$. A.O. Ozioko of the Department of Plant science and Biotechnology, Faculty of Biological Sciences, University of Nigeria Nsukka. Specimens were kept in herbarium with numbers KA-067-B-14, PM-054-B-014 and PA-041-C-014 respectively for referral purposes. The leaves were picked off the stem and carefully cleaned of debris and stored at $4^{\circ} \mathrm{C}$ till use.

\section{Chemical reagents}

All the solvents and chemicals were of analytical grade and obtained Sigma Aldrich, Germany except where otherwise stated: formaldehyde, ammonium sulphate, sodium chloride, potassium chloride, disodiumand dipotassium- hydrogen phosphates, hydrochloric acid, Distilled water (Science Laboratory and Equipment Center Unit of the University of Nigeria). Freshly prepared and sterilized phosphate buffered saline (PBS) was used.

\section{Other materials}

$100 \mathrm{ml}$ beaker, spatula, separating funnel, measuring cylinder, weighing balance, syringes, dialyzing membrane microtitre plates, needles, hand gloves, filter paper (Whatman No. 2 and 4).

\section{Methods}

\section{Extraction and purification of plant materials}

The leaves of the Loranthus micranthus parasitic on kola acuminata were washed with distilled water and homogenized in minimum volumes of phosphate buffer with a blender. The homogenate was stirred overnight centrifuged at 10,000 g for 10 minutes and filtered using a Whatman No. 4 filter paper. The filtrate was subjected to ammonium sulphate fractionation (30\%). The precipitate formed was re-dissolved in $90 \%$ ammonium sulphate in minimum volume of water and dialyzed against phosphate buffered saline. The process was repeated for each of the plant parasitic on Pentaclathra macrophylla and Persia americana. The extracts and fractions were evaluated for phytochemical constituents using standard methods. The plant collection was based on approval granted in accordance with the
United Nation Chatter on Preservation of Biodiversity as operational in the University of Nigeria.

\section{Collection and preparation of blood sample}

Experimental protocols were executed in accordance with the guidelines of the Ethics Committee of the University of Nigeria as registered by the National Health Research Ethics Committee of Nigeria (as per the approved ref: NHREC/05/01/2008B). The animal care and handling was in line with the internationally accepted principles for laboratory animal use and care as found in the European Community guidelines (EEC Directive of 1986; 86/609/EEC). Exactly ten (10) $\mathrm{ml}$ of white albino mice blood was collected in a heparinized bottle from the Department of Veterinary Medicine, University of Nigeria Nsukka and kept at $4^{\circ} \mathrm{C}$ to preserve them till the time of use. $10 \mathrm{ml}$ of the blood sample was centrifuged at $10,000 \mathrm{~g}$ for 5 minutes at room temperature. The red blood cells $\left(1 \times 10^{9} \mathrm{cell} / \mathrm{mm}^{3}\right)$ obtained were then washed by centrifugation at $10000 \mathrm{~g}$ for 5 minutes at room temperature with sterile phosphate buffer saline ( $\mathrm{pH}$ 7.2). This was repeated twice after which the cells were mixed 3\% formaldehyde in EDTA bottle and allowed to stir gently overnight before it was centrifuged at $10000 \mathrm{~g}$ for 5 minutes, the following day. The centrifuged red cells were then washed again as before, three times with phosphate buffer saline $(\mathrm{pH}$ 7.2) after which the cells were collected into a stopped and phosphate buffered saline was added to make the cell $4 \%$ thereafter, it was stored at $4^{\circ} \mathrm{C}$ prior to use.

\section{Pharmacological screening: Haemagglutination test}

Agglutination of the red blood cells by the crude extract and the various fractions that were obtained during purification was estimated as described by Osadebe and Omeje, 2009. Briefly, a two-fold serial dilution of the lectin-rich fractions (concentration $\approx 10 \mu \mathrm{g} / \mathrm{ml}$ ) was mixed with $5 \mu \mathrm{l}$ of a $4 \%$ suspension of mouse erythrocyte $\left(1 \times 10^{9}\right.$ cell/ $\mathrm{mm}^{3}$ ) in phosphate buffered saline, $\mathrm{pH} 7.2$ at room temperature in micro-titre plates. The plates were left undisturbed for $1 \mathrm{hr}$ at room temperature in order to allow for agglutination of the erythrocytes to take place. The haemagglutination titre of the lectin expressed as the reciprocal of the highest dilution exhibition visible agglutination of erythrocytes was reckoned as one haemagglutination unit. Specific activity is the number of haemagglutination units per $\mathrm{mg}$ protein.

\section{Results and discussion}

The extraction process afforded yields of $22 \%, 18 \%$ and $25 \%$ respectively for Loranthus micranthus parasitic on Kola acuminata,

Table 1. Result of Phytochemical tests on extracts and fractions.

\begin{tabular}{|l|c|c|c|c|}
\hline & K. acuminata & P. macrophylla & P. americana & Fractions \\
\hline Phytoconstituents & & & & \\
\hline Carbohydrate & ++ & ++ & + & +++ \\
\hline Protein & ++ & + & ++ & +++ \\
\hline Reducing Sugar & + & + & ++ & - \\
\hline Alkaloids & +++ & ++ & + & - \\
\hline Glycosides & ++ & + & + & - \\
\hline Flavonoids & +++ & ++ & ++ & - \\
\hline Tannins & +++ & ++ & ++ & - \\
\hline Resins & ++ & + & +++ & - \\
\hline Acidic compounds & + & + & ++ & - \\
\hline Saponins & ++ & ++ & ++ & - \\
\hline Oils & + & ++ & + & - \\
\hline Terpenoids & ++ & + & + & - \\
\hline Steroids & ++ & + & ++ & - \\
\hline
\end{tabular}

Key: (-) absent; (+) Low; (++) Medium; (+++) High in concentration 
Omeje EO (2015) Enhanced haemagglutination and phytochemical evaluation suggest significant presence of glycoproteins (Lectins) in semi-purified fractions of eastern Nigeria Mistletoe, Loranthus micranthus Linn

Table 2. Haemagglutination assay with extracts and fractions ${ }^{(s)}$.

\begin{tabular}{|c|c|c|c|c|c|c|c|c|c|c|c|c|c|c|}
\hline \multirow[t]{3}{*}{ Sample } & \multicolumn{4}{|c|}{$\mathbf{A}$} & \multicolumn{4}{|c|}{ B } & \multicolumn{4}{|c|}{ C } & \multicolumn{2}{|c|}{ PBS } \\
\hline & \multicolumn{3}{|c|}{ Activity } & \multirow[t]{2}{*}{ Time } & \multicolumn{3}{|c|}{ Activity } & \multirow[t]{2}{*}{ Time } & \multicolumn{3}{|c|}{ Activity } & \multirow[t]{2}{*}{ Time } & \multirow[t]{2}{*}{ Activity } & \multirow[t]{2}{*}{ Time } \\
\hline & A1 & A2 & A3 & & B1 & B2 & B3 & & $\mathrm{C} 1$ & $\mathrm{C} 2$ & $\mathrm{C} 3$ & & & \\
\hline Crude & 2.2 & 2.4 & - & $50 \mathrm{~min}$ & 2.1 & - & - & $120 \mathrm{~min}$ & 2.1 & 2.2 & - & $60 \mathrm{~min}$ & - & $120 \mathrm{~min}$ \\
\hline $\mathrm{NH}_{4} \mathrm{SO}_{4}$ & - & 2.5 & 4.2 & $75 \mathrm{~min}$ & 2.2 & - & 2.2 & $120 \mathrm{~min}$ & - & 2.1 & 2.2 & $75 \mathrm{~min}$ & - & $120 \mathrm{~min}$ \\
\hline Dialyzed & 8.2 & 8.3 & 2.6 & $50 \mathrm{~min}$ & 2.8 & - & 2.8 & $45 \mathrm{~min}$ & 8.6 & 2.2 & - & $30 \mathrm{~min}$ & - & $120 \mathrm{~min}$ \\
\hline
\end{tabular}

(s) Represents the expression of degree of agglutination as the $-\log 2$ units of the highest dilution that showed significant agglutination; $\mathrm{A}=$ mistletoe from $K$. acuminata; $\mathrm{B}=$ mistletoe from P. macrophylla; $\mathrm{C}=$ mistletoe from $P$. americana; $\mathrm{A} 1-\mathrm{C} 3$ are serial dilutions; $\mathrm{PBS}=$ Phosphate buffered saline.

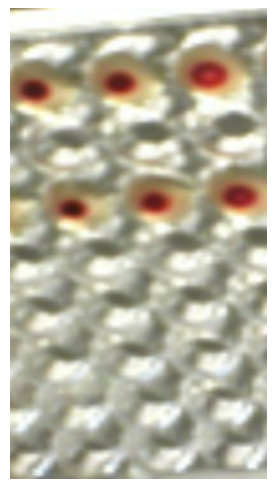

(a)

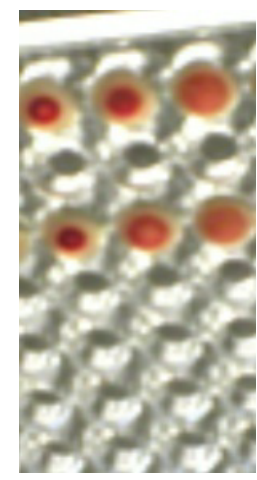

(b)

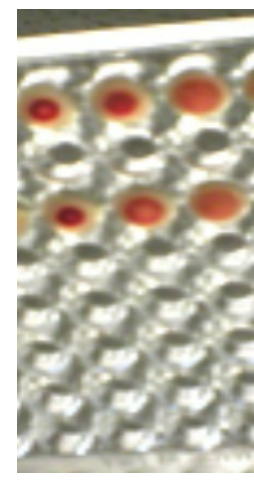

(c)

Figure 1. Haemagglutination of mouse-red blood cell by fractions from Kola acuminata (a), Persia americana (b), Pentaclathra macrophylla (c).

Pentaclathra macrophylla and Persia americana which are in agreement with previous reports (Omeje and Osadebe 2009) and implies satisfactory extraction efficiency for the maceration method. Phytochemical investigation on the extracts gave positive reactions for alkaloids, tannins, flavonoids, resin, proteins, carbohydrate, reducing sugars but only carbohydrates and proteins were established present in the dialyzed fraction (Table 1). This suggests that the ammonium sulphate-based dialysis successfully sequestered out proteins conjugated to carbohydrates which possibly are glycoproteins. The data presented from this study showed that the extract of the leaves of Loranthus micranthus parasitic on Kola acuminata contained adequate amount of hemagglutinating protein (Lectin) than the other species of host plant as this is evidenced in Table 2 and Figure 1. Although, at present, we do not understand completely why the extract from Kola acuminata mistletoe showed more activity, the trend agrees with our previous findings (Osadebe and Omeje 2009). It has been strongly established that the biological activities of mistletoes are both hosttree and season dependent $[11,12]$. In other words, the concentration of bioactive secondary metabolites varies from host tree to host tree and with the season as well as the environment. Most convincingly, we opine that since Kola acuminata (Kola nut tree) is a highly revered traditional and economic tree grown close to human habitations, it is hardly exposed to seasonal bush burning and associated degradation of accumulated secondary metabolites being experienced by other host trees that grow more in bushy farm lands. It is in line with this and from the rich phytochemical composition of the mistletoes from Kola acuminata that we at this time link with its observed high activity. This finding strongly suggests a significant presence of lectins in the obtained fractions and opens frontiers for further analysis of the fraction so as to obtain the exact constitution and biological properties of lectins of mistletoes in eastern Nigeria. It is therefore recommended that future works in this area should focus on complete characterization of the glycoproteins of the eastern Nigeria mistletoes.

\section{Acknowledgement}

The authors are grateful to the Indian Government that awarded a CV-Raman Postdoctoral fellowship to Dr. E. O. Omeje.

\section{References}

1. Yoon TJ, Yoo YC, Kang TB, Her E, Kim SH, et al. (2001) Cellular and humora adjuvant activity of lectins isolated from Korean mistletoe (Viscum album coloratum). Inter Immunopharmacol 1: 881-889. [Crossref]

2. Park HJ, Hong JH, Kwon HJ, Kim Y, Lee KH, et al. (2010) TLR4-mediated activation of mouse macrophages by Korean mistletoe lectin-C (KLM-C). Biochem Biophys Res Commun 396: 721-725. [Crossref]

3. Gao W, Su Y, Chen S, Zhang J, Wang Y, et al. (2013) Mushroom lectin enhanced immunogenicity of HBV DNA vaccine in C57BL/6 and HBsAg-transgenic mice. Vaccine 31: 2273-2280. [Crossref]

4. Sung NY, Byun EB, Song DS, Jin YB, Kim JK, et al. (2013) Effect of gamma IR radiation on mistletoe (Viscum album) lectin-mediated toxicity and immunomodulatory activity. FEBES Open Bio 3: 106-111. [Crossref]

5. Souza MA, Carvalho FC, Ruas LP, Ricci-Azevedo R, Roque-Barreira MC (2013). The immunomodulatory effects of plant lectins: a review with emphasis on ArtinM properties. Glycoconj J 30: 641-657. [Crossref]

6. 6.Langer M, Möckel B, Eck J, Zinke H, Lentzen H (1999). Site specific mutagenesis of mistletoe lectin: the role of RIP activity in apoptosis. Biochem Biophys Res Commun 264: 944-948. [Crossref]

7. Kang TB, Yoo YC, Lee KH, Yoon HS, Her E, et al. (2010) Korean mistletoe lectin (KML-IIU) and its subchains induce nitric oxide $(\mathrm{NO})$ production in murine macrophage cells. J Biochem Sci 15: 197-204. [Crossref]

8. Osadebe PO, Omeje EO (2009) Comparative toxicities and immunomodulatory potentials of five Eastern Nigeria mistletoes. J Ethnopharmacol 126: 287-293. [Crossref]

9. Omeje EO, Osadebe PO, Akira K, Abdessamad D, Esimone CO, et al. (2011) Steroids and triterpenoids from the leaves of the Eastern Nigeria mistletoe with immunomodulatory potentials. Phtyo Lett.

10. Omeje EO, Mohd PK, Osadebe PO, Deepshika T, Faheem K, et al. (2014) Analysis of constituents of the eastern Nigeria mistletoe, Loranthus micranthus Linn revealed presence of new classes of osteogenic compounds. Journal of Ethnopharmacology 151 643-651. [Crossref]

11. Osadebe PO, Omeje EO, Uzor PF, David EK, Obum DC (2010a) Seasonal variation of the antidiabetic activity of Loranthus micranthus methanol extract. Asian Pacific Journal of Tropical Medicine: 1-5.

12. Osadebe PO, Omeje EO, Nworu CS, Esimone CO, Uzor PF, et al. (2010b) Antidiabetic principles of Loranthus micranthus Linn. parasitic on Persea americana. Asian Pacific Journal of Tropical Medicine: 619-623.

Copyright: (C2015 Omeje EO. This is an open-access article distributed under the terms of the Creative Commons Attribution License, which permits unrestricted use, distribution, and reproduction in any medium, provided the original author and source are credited. 